Article

\title{
Functional Characterisation of New Sesquiterpene Synthase from the Malaysian Herbal Plant, Polygonum Minus
}

\author{
Nor Azizun Rusdi ${ }^{1,2}$, Hoe-Han Goh ${ }^{1}$ (D), Suriana Sabri ${ }^{3,4}$ (D), Ahmad Bazli Ramzi ${ }^{1}$, \\ Normah Mohd Noor ${ }^{1}$ and Syarul Nataqain Baharum ${ }^{1, *}$ \\ 1 Institute of Systems Biology (INBIOSIS), Universiti Kebangsaan Malaysia, Bangi 43600 UKM, Selangor, \\ Malaysia; azizun@ums.edu.my (N.A.R.); gohhh@ukm.edu.my (H-H.G.); bazliramzi@ukm.edu.my (A.B.R.); \\ normah@ukm.edu.my (N.M.N.) \\ 2 Institutes for Tropical Biology and Conservation, Universiti Malaysia Sabah, Jalan UMS, \\ Kota Kinabalu 88400, Sabah, Malaysia \\ 3 Enzyme and Microbial Technology Research Center, Faculty of Biotechnology and Biomolecular Sciences, \\ Universiti Putra Malaysia, UPM Serdang 43400, Malaysia; suriana@upm.edu.my \\ 4 Department of Microbiology, Faculty of Biotechnology and Biomolecular Sciences, \\ Universiti Putra Malaysia, UPM Serdang 43400, Malaysia \\ * Correspondence: nataqain@ukm.edu.my; Tel.: +603-892-145-50; Fax: +603-892-133-98
}

Received: 23 March 2018; Accepted: 31 May 2018; Published: 4 June 2018

\begin{abstract}
Polygonum minus (syn. Persicaria minor) is a herbal plant that is well known for producing sesquiterpenes, which contribute to its flavour and fragrance. This study describes the cloning and functional characterisation of PmSTPS1 and PmSTPS2, two sesquiterpene synthase genes that were identified from P. minus transcriptome data mining. The full-length sequences of the PmSTPS1 and PmSTPS2 genes were expressed in the E. coli pQE-2 expression vector. The sizes of PmSTPS1 and PmSTPS2 were $1098 \mathrm{bp}$ and $1967 \mathrm{bp}$, respectively, with open reading frames (ORF) of 1047 and $1695 \mathrm{bp}$ and encoding polypeptides of 348 and 564 amino acids, respectively. The proteins consist of three conserved motifs, namely, Asp-rich substrate binding (DDxxD), metal binding residues (NSE/DTE), and cytoplasmic ER retention $(\mathrm{R} \times \mathrm{R})$, as well as the terpene synthase family $\mathrm{N}$-terminal domain and C-terminal metal-binding domain. From the in vitro enzyme assays, using the farnesyl pyrophosphate (FPP) substrate, the PmSTPS1 enzyme produced multiple acyclic sesquiterpenes of $\beta$-farnesene, $\alpha$-farnesene, and farnesol, while the PmSTPS2 enzyme produced an additional nerolidol as a final product. The results confirmed the roles of PmSTPS1 and PmSTPS2 in the biosynthesis pathway of P. minus, to produce aromatic sesquiterpenes.
\end{abstract}

Keywords: farnesol; nerolidol; Polygonum minus; sesquiterpene synthase

\section{Introduction}

Over the last 25 years, nearly 65,000 chemical structures of terpenoids have been discovered, making terpenoids the class of natural products with the greatest structural diversity $[1,2]$. Terpenoids are involved in a variety of important functions in regulating plant growth (especially for terpenoid lactones) and play an ecological role in attracting pollinators [3]. Terpenoids are grouped into different classes based on the number of 5-carbon building blocks [4-7]. All terpenoids are derived from the common phosphorylated five-carbon (C5) building units, isopentenyl diphosphate (IPP) and dimethylallyl diphosphate (DMAPP) [8]. There are two major pathways involved in the biosynthesis of terpenoids, namely, the mevalonate (MVA) pathway, which is primarily found in eukaryotes, and the methylerythritol phosphate (MEP) pathway (non-mevalonate pathway), which is primarily found in prokaryotes and plant chloroplasts [9-11]. For sesquiterpene biosynthesis, IPP and DMAPP undergo condensation to form farnesyl pyrophosphate 
(FPP), which is catalysed by the enzyme FPP synthase. The resulting linear FPP undergoes electrophilic cyclisation and rearrangement to form acyclic and non-acyclic sesquiterpenes, based on the sesquiterpene synthase enzyme reactions [12,13].

In particular, monoterpenes and sesquiterpenes are commonly present in plant essential oils, which are widely utilised for commercial purposes, such as fragrances, cosmetics, pharmaceuticals, medicine, biofuel precursors, and industrial materials [14,15]. To date, over 7000 sesquiterpenes (C15) with different hydrocarbon skeletons and stereo-chemically structures have been reported [16]. Studies on naturally derived 15-carbon terpenoids in aromatic herbal plants as anti-malarial, anti-microbial, and insecticidal agents have also increased over the last several years [17]. Hence, many sesquiterpenes are founds as major components of fruits and vegetables, floral scents, and essential oils of herbs. In previous studies, a number of genes encoding the sesquiterpene enzymes, which control the key steps of secondary metabolic pathways, have been extensively cloned and characterized from a number of herbal plant species. For example, squalene synthase from Tripterygium wilfordii [18], germacrene A synthase from Achillea millefolium [19], drimenol synthase from Valeriana officinalis [20], E-E-farnesol synthase and $\alpha$-bisabolene synthase from Gingko biloba [21], $\alpha$-humulene synthase from Zingiber zerumbet Smith [22], (+)-epi- $\alpha$-bisabolol synthase from Lippia dulcis [23], $\beta$-caryophyllene synthase from Ocimum basilicum L. [24], $\alpha$-humulene synthase from Zingiber zerumbate Smith [25], and Germacrene D synthase from Zingiber officinale [26].

Polygonum minus (syn. Persicaria minor) is a herbal plant that originated from Southeast Asia and belongs to the Polygonaceae family. In Malaysia, P. minus is locally known as a 'kesum', and is commonly used as a food additive and flavouring agent. Many studies have been carried out because of the popularity of the $P$. minus as a potential medicinal plant with high antioxidant and antimicrobial activities and strong anti-inflammatory properties [27-30]. P. minus is an economically important herbal plant because of its essential oils, which cause it to emit a strong scent from a simple mixture of terpenoid hydrocarbons (monoterpenoids and sesquiterpenoids), including $\beta$-farnesene, $\alpha$-farnesene, nerolidol, farnesol, caryophyllene, $\alpha$-bergamotene, and drimenol [31,32]. Other characteristic components that have been identified from P. minus include aldehydes (decanal and dodecanal), esters, and organic acids [33]. Moreover, recent studies have revealed that the sesquiterpenes compounds are the main contributors to the characteristic fragrance of this plant [34]. These studies have shown the potential for developing P. minus as a resource to produce natural products. While many structurally diverse secondary metabolites, especially terpenoid compounds, have been identified in P. minus, its biosynthesis of major constituents remains unclear because of the limited genomic information that is available for this plant. Therefore, this plant is investigated for the isolation and characterisation of novel sesquiterpene synthase genes. Additionally, there is not much work on sesquiterpene synthase from P. minus, especially at the genetic level, as it is still very scarce.

In previous studies, several works on sesquiterpene synthases were identified. The first $P$. minus putative sesquiterpene synthase gene was cloned and expressed in E. coli systems [35]. Song et al. [36] successfully overexpressed a sesquiterpene synthase, $P m \mathrm{STS}$, in metabolically engineered gram-positive bacteria, Lactococcus lactis, with the MVA pathway. Then, a structural study was performed that demonstrated an active catalytic site with the same gene sequence [37]. The encoded enzyme was named $\beta$-sesquiphellandrene synthase, based on the principal product that was formed. In a subsequent study, the influence of jasmonic acid treatment on the expression level of the Persicaria minor sesquiterpene synthase (PmSS) gene was reported [38]. Until very recently, the purification and overexpression of P. minor sesquiterpene synthase encoded as PmSTS recombinant protein in $\mathrm{pET} 28 \mathrm{~b}$ vector, using the E. coli BL21 (DE3) strain, were reported [39]. All of the studies on P. minus that have been mentioned above were based on the same sesquiterpene synthase. In order to understand the terpenoid metabolism of P. minus, the potential gene for terpene synthases must be isolated and studied. Therefore, in this study, we described the cDNAs isolation and characterisation of two new sesquiterpene synthases (STPS) that were responsible for the formation of two key aromatic compounds, which made substantial contributions to the flavour and fragrance of $P$. minus essential oil. The results could have provided a foundation for the further exploration of gene function in P. minus, and helped to reveal the regulation of terpenoid biosynthesis. 


\section{Results}

\subsection{Screening and Isolation of Sesquiterpene Synthase Gene from P. minus}

Two new candidates of sesquiterpene synthase genes, PmSTPS1 (comp62410_co_seq6) and PmSTPS2 (comp47018_c0_seq1), were successfully identified through the sequence analysis of $P$. minus transcriptome [40]. The $1098 \mathrm{bp}$ PmSTPS1 transcript contained an open reading frame (ORF) of $1047 \mathrm{bp}$, encoding 348 amino acids with a calculated molecular mass of $40.9 \mathrm{kDa}$ and an isoelectric point (pI) of 6. 15 (Figure S1). The ORF of PmSTPS1 started from the nucleotide position at 25 and ended at position 1071. The deduced amino acid sequence of PmSTPS1 (GenBank accession no. MG921605) showed no signal peptide. A ProtParam analysis of the predicted amino acid sequence of PmSTPS1 revealed 47 negatively charged residues (Asp and Glu) and 52 positively charged residues (Arg and Lys), which represented the aliphatic index of this protein. This was a positive factor for the increased thermostability of the globular protein. The second sesquiterpene synthase transcript, PmSTPS2 (GenBank accession No: MG921606), was 1974 bp long and had an ORF of 1695, which encoded a polypeptide of 564 amino acids (Figure S2). The ORF of PmSTPS2 started from the nucleotide position at 97 and ended at position 1798. The calculated molecular mass of the mature protein was approximately $65.96 \mathrm{kDa}$, with a predicted pI of 5.75. A ProtParam analysis of the predicted amino acid sequence of PmSTPS2 identified 83 negatively charged residues (Asp and Glu) and 70 positively charged residues (Arg and Lys).

Based on the BLASTx analysis, the predicted amino acid sequences of PmSTPS1 (Table 1) and PmSTPS2 (Table 2) had the closest hit to drimenol synthase from Persicaria hydropiper, with a $96 \%$ and $46 \%$ identity, respectively. The predicted amino acid sequence of PmSTPS2 was consistent with those of other sesquiterpene synthases encoding proteins of 550-580 amino acids, with molecular weights of 60-70 kDa. Conversely, the length of PmSTPS1, with only 348 amino acids, was much shorter than that of the other sesquiterpene synthases. Therefore, only PmSTPS2 met the range of other reported plant terpene synthases [21,41-45].

The presence of the conserved domains in the PmSTPS1 and PmSTPS2 proteins was consistent with and similar to that of the other terpene synthase features. The terpene synthase family N-terminal domain (PF01397) and the synthase family C-terminal metal-binding domain (PF03936) contained highly conserved aspartate-rich motifs (DDxxD), which were essential for enzyme-substrate binding and catalytic function. The first aspartate-rich motif played a role in the determination of the chain length for the resulting prenyl pyrophosphate.

Based on the multiple sequence alignment of PmSTPS1 (Figure 1), several conserved motifs that were found in typical terpene synthases were identified, including the DDxxD (residue 100-104) and NSE/DTE (residue 245-253) motifs. The DDxxD and NSE/DTE motifs flanked the entrance of the active site. In addition to these motifs, there was a highly conserved arginine-rich RxR motif, which was involved in the complexing of the diphosphate group, after the ionisation of FPP $[18,39]$. The RxR motif was located at 45 amino acids, upstream of the first DDxxD motif. For PmSTPS2, the conserved arginine-rich (RxR) region at amino acid position 278-281 was conserved in all of the terpene synthases [19]. Moreover, the aspartate-rich motif of DDxxD, which might have been the $\mathrm{Mg}^{2+}$ binding site, was located at position 314-318 of the amino acid sequence. Another metal binding motif, the NSE/DTE motif, was detected at amino acid position 461-467 (Figure 1). The less conserved motif NSE/DTE, apparently evolved from a second motif that was conserved in prenyl transferase. In general, these motifs were located on the opposite sides of the active site [6,7]. The metal binding residues appeared as NSE in most microbial and fungal cyclases and as DTE in most plant cyclases.

Table 1. BLASTx analysis of PmSTPS1 with the NCBI protein database.

\begin{tabular}{lccccr}
\hline \multicolumn{1}{c}{ Description } & Organism & Score & E-value & Identity (\%) & Accession \\
\hline Drimenol synthase & Persicaria hydropiper & 678 & 0.0 & 96 & AHF2284.1 \\
\hline Putative sesquiterpene synthase & Persicaria minor & 664 & 0.0 & 95 & ALO69830.1 \\
\hline Delta-cadinene synthase isozyme A & Theobroma cacao & 393 & $5 \times 10^{-129}$ & 54 & XP_007021123.1 \\
\hline Predicted: probable sesquiterpene synthase & Beta vulgaris subsp. vulgaris & 389 & $3 \times 10^{-127}$ & 54 & XP_010694277.1 \\
\hline Predicted: probable terpene synthase 2 & Rocinus communis & 381 & $3 \times 10^{-124}$ & 52 & XP_002523635.1 \\
\hline
\end{tabular}


Table 1. Cont.

\begin{tabular}{lccccc}
\hline \multicolumn{1}{c}{ Description } & Organism & Score & E-value & Identity (\%) & Accession \\
\hline Probable sesquiterpene synthase & Santalum murrayanum & 379 & $1 \times 10^{-123}$ & 54 & F6M8H1 \\
\hline$(-)$-germacrene D synthase-like isoform X2 & Citrus sinensis & 379 & $1 \times 10^{-123}$ & 52 & XP_015384843.1 \\
\hline
\end{tabular}

Table 2. BLASTx analysis of PmSTPS2 with the NCBI protein database.

\begin{tabular}{lccccc}
\hline \multicolumn{1}{c}{ Description } & Organism & Score & E-value & Identity (\%) & Accession \\
\hline Drimenol synthase & Persicaria hydropiper & 492 & $3 \times 10^{-164}$ & 46 & AHF2284.1 \\
Probable sesquiterpene synthase & Beta vulgaris subsp. vulgaris & 492 & $3 \times 10^{-164}$ & 43 & XP_010694277.1 \\
Valencene synthase-like & Vitis vinifera & 489 & $2 \times 10^{-163}$ & 44 & NP_001268028.1 \\
Germacrene A synthase & Vitis vinifera & 489 & $2 \times 10^{-163}$ & 44 & ADR66821.1 \\
Putative sesquiterpene synthase & Persicaria minor & 484 & $3 \times 10^{-161}$ & 45 & ALO69830.1 \\
Predicted: (-)-germacrene D synthase & Vitis vinifera & 479 & $4 \times 10^{-159}$ & 42 & XP_002282488.1 \\
(E)-beta-caryophyllene synthase & Vitis vinifera & 477 & $1 \times 10^{-158}$ & 45 & ADR74194.1 \\
\hline
\end{tabular}

MG921606

$X P \quad 007021123$. F6) 8 H 7.1

XP 002282488.1

$\operatorname{ADR} 74194.1$

NE_001268028.1

ADR 65821.1

XP 010694277.1

MG $\overline{9} 21605$

AHF22834.1

ALO69830.1

MG921606

XP 007021123.1

F6M 8 H 7.1

XP 002282488.1

ADR 74194.1

NP 001268028.1

ADR 66821.1

XP_010694277.1

MG 921605

AHF22834.1

ALO69830.1

\section{MG921606}

XP 007021123.1

Fб $\bar{M} 8 \mathrm{H} 7$.

XP_002282488.1

ADĒ 74194.1

NP 001268028.1

ADR 66821.1

$\mathrm{XP} 010694277.1$

MG 921605

AHF 22834.1

AL069830.1

MG921606

XP_007021123.1

Éต̄ $8 \mathrm{H} 7$.

XP 002282488.1

ADR 74194.1

NP 001268028.1

ADR 66821.1

XP 010694277.1

MG $\overline{9} 21605$

AFF22834.1

ALO69830.1

MG921606

XP 007021123.1

E5M 8177.1

XP 002282488.1

ADĒ 74194.1

NP 001268028.1

$\operatorname{AD} \bar{R} 66821.1$

XP 010694277.1

MG 921605

AHF22834.1

AL069830.1

MG921606
-----MSSQTVVLASPPVAAQTKPDVTRPIAKFHPCVWGNHFLNYTPSDEEV--VTERKM -----MSSLASSSTLPVSTNDSMSNENRRSTKFHPS IWGDLFLSFPSKVNV---DT T TQT ----MENQKMP I SSVPN--LKDLNMI SRP IANFPPS IWGDRF INYTCEDEN--DQTQKER -----MSVPLSVSVTP I LSQR IDPEVARHEATYHPNEWGDR FLHYNPDDD FCGTHACKE ------MSTQVSECPL--VQI PKPENRPRAKFH PNIWGDLFI TYTPEDEV--SRACKEK ------MS IQVSTCPL--VQIPKPEHRPMAE FHPS IWGDQF IAYTPEDED--TRACKEK -------MSTOVSTCPI--VOT PKPFHRPMAFFHPSTWGDQFTAYTPEDED--TRACKFK ----------MEQTANSGNCRPLAHYHPSLWGDHFLNY TPPDEL--'TQRQREF --------MSTAVNVPSAVRPADKRPIAS FHPSPWGDY FLKYVPCDQV--TQAKMED

EIESIKI EVRKELLKI--A-DRPLESMKLIDAIERLGVSYHFEKEIEESLKQAYDAYKKN HYEZLKQEVRRMLRVP--T DNQLSQKLRLIET I KRLGVSYHFEREI EDVLQN I YDQ---QVEEIKEQVRRELAAT--V-DKPLQQINI IDATQRLGIAYLFENEIEESLKHIYLHTYVE QIQEIKE EVRKSLEAT--A-GNTSQLIKLIDS IQRLGLAYHFERE IEEALKAMYQTYTLQVTOTODVRRETMAR-A GNPSOT-

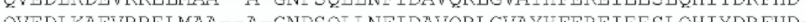

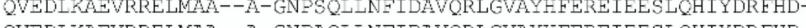
QVEDIKA TVRRELMAA--A-GNPAQLLNFIDAVORLGVAYHFEREIEESLQHIYDRFHDTVKEIKEIVRRKLLGFAEDR---KQRLVVIDVVEQLGVAYHFTAEIEDNLQ FYSNYSQD EVKKVEIDVKKELRKLAKAVGKPLELINFIDVVERLGVGYRLEOEIEDLVOAIFDNDKFG FVKKVETDVKKELRKLAKAVGKPLELINFIDVVERLGVGYRLTQRIEDLVQTI FDNDKFC

DQ--DSSIDLYHTSLSFRILRQHGYYVS-SEIFSKFIDEHGSFIGSLKSDIMGLLSLYDA --DY-KDDNLEVTSLR FRLLREHG FNVO-CET FNKFKDDKGNFKVSLKSDVKGLLELYFA NNCFEGSDDLYSVAL,WFRLLRQNGYKVS-CDVFNKFRDNEGNFKNNLMEDAKGLLELYEA --VDD-NDHLTTVSLLFRLLRQEGYHI - SDVFKKFMDEGGNFKESLVGDLPGMLALYEA --ADDTNDDLYNIALRFRLLRQQGYNIS-CGI FNKFKDEEGSFKEDLISNIQGMLGLYEA --ADDTEDDLYNIALQFRLLRQQGYNIS-CGI FNKFKDEKGSFKEDLI SNIQGMLGLYEA --ADDTEDDLYNIALQFRLLRQQGYNIS-CGI FNKFKDEKGSFKEDLISNVQGMLGLYEA DEI--Y YNDLHYVSLRFRLLROHGFYAS-SDVFYKFKNTDGHFKESLKNDVVGILNFYEA

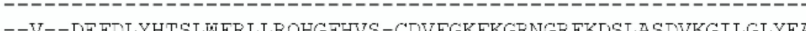
--V--HEFDLYHTSLWFRLLROHGFHVS-CDVFGKFKGKNARFKDSLASDVKGILGLYEA

AYLRGNGDTIMEKALEFSWHLKVVAM-EKDHPLAPQICRALVYPIHKGVVLIESRHYIS AHIRTHGEHILEEALAFTTTHLESAKTSLCEYPISVLVSHARKRPIRKGLQRLEARRFIS THVS IHGEEMLDDALEFTKTRLESVVS-HLNYPLAEQVRHALYQPLHRGLPRLEAVYFFR AHIMVHGEDILDEALGFT TAHLQSMAI -DSDNPLTKOVIRALKRPIRKGLPRVEARHY IT AHIRVHGEDILEEALAFTTTHLKAKVE-SLGCPLAEQVAHALKRPIRKGLERLEARWYY IS AHT RVIGSTI

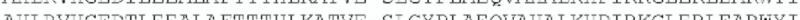
SYIRVHGENILDEGVEFT TTOLKSIVSNL-SDPLATOVTOALKLPLHKGVTRLLSRHY I SHVRTHGDDTLDEALVFT THLKAVVTNQPNHPLVPQVTHALMQPYHKGMPRLESRHF IA SHVRTHGDDTLDEALVTT THLKAVVTNQPNHPLVSQVTHALMQPYHKGMPRLESRHFIA

FYEKQP FHMRSLLRYSKLE FNVRQSLHKEELKDLTMWWRSFEFPKTEPEI-RDRVVEAYL IYQEDGSHDKTLLKFAKLDFSLVONLHKEELSKISRWWKDLDFKRQLPFA-RDRI VEGYE TVTAHASTNKATIKTAKLDFNLIOS THKKEISDTARUWKSIDTAAKRPFA-RDR -YOPDOS I IYQDEAFHDKTLLKLAKLD FNLVQS IHKEELSNLARWWKKLDFATKLPFA-RDRI VEGY IYQDFASHDKTLLKLARKLDFNLVQSLHKEELSNLARWWKELDFATKLPEA-RDR HVGY LYQDE.ASHDKTLLKLAKLDFNLVQSLHKEELSNLARWWKELDFATKLPEA-RDR VVEGY TYEAHPIHDETLLKEAKLDFNLLQTYHLKELRDLSRWWRSLSFGSKLPFA-RDR AAEVYE FYEKDPRHDKTLLKEGKLDFNLVQALHKKELKDKTRWWKDLDMHAKMPFPSRDR PECYF F'YEKDPYHDKTLLKEGKLDFNLVQALHKKELKDLSRWWKDLDMHAKMPEPSRDR PE'GY FYEKDEYHDKTLLKFGKLDFNLVOALHKKELKDLSRWWKDLDMHAKMP FPSRDRJ PEGYF

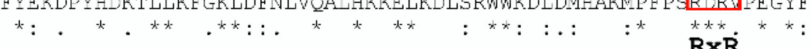
NSVSVFHDPKESVARVVYTKAFLLLTV DDIYD \$YGTIEELEAFTKAIERWDKST IDELP

Figure 1. Cont. 


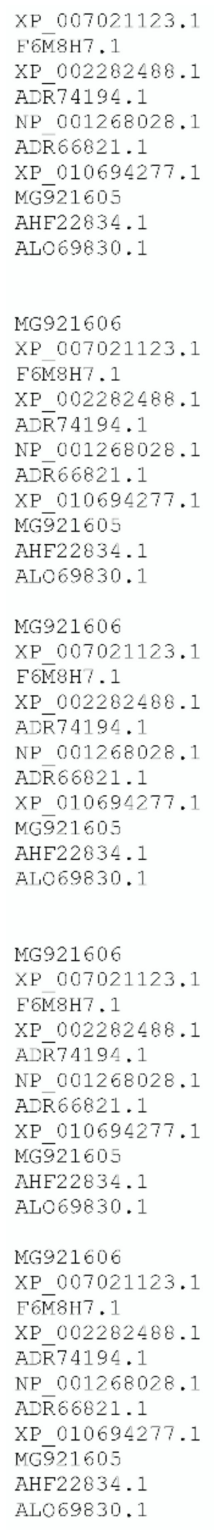

WILGVYFEPQYSFARQILTKATVMASTMDDIYDAYGTFEETQLFTKATERWDTNCMDRLP WVLGVY EEPQYSLARK I I I KVETMIST I DDIYDAYGT LDELKLETKAMQRWDVGSLDQLP WILGVYFEPQYYLARR I IMKVEGVLSIVDDIYDAYGTFEELKLFTEAIERWDASS IDQLP WIVGVYFEPQYLWAIR I IRKI IVMT TVIDD IYDAYGTEEEIKHFTEAIERWDINS IDHLP WTLGVYFE POYSRARR I LKKLESMAS I IDD I Y DAYGTLEELOPETEAIERWDTKSTDHLP

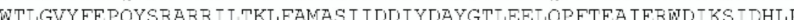
THZ GVYEPQYALG WI GIFYEPQYALG

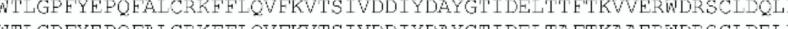
WTLGPFYEPQEALCRKTFLONKTSIVDDIYDAYGIIDELTAFTKAIERMDSCLDEL WTLGP FYEPOEAISRKF FIQVEKVTS IVDD IYDAYGT IDELTAFTKAAERWDHSCIDELP $:::^{*}:: \quad \cdot \quad: \quad::^{* *}:^{* *}{ }^{* *}::^{*}::^{*} \ldots::^{* *}::^{* *}$

SYMKLFYE IQYDSYKQFEDDVATLGIKNYVQYAVKEVITLSKAYLQEARWCKMKYVPTED AYMKLFYKALLDVYEZMEZVMTKOVKSYRVKYAKEAMKQLSOAY FVEAKWYHENYVPTVE

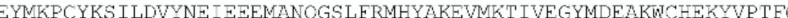
DYUTUCYOAL OVYTY DVTYCY DYNK EYMLEYTLLDLYR IDQELEKYGNQYRVYAKEVLKSQVRAYAAEAKWSHEGYIPTI EYMKLFYVTLLDLYKEIDQELEKYGNOYRVYYAKEVLKSQVRAYFAEAKWSHEGYIPTIE DYMKLTYEALLDTFDGFIQSLANEGRSQLVSYVREMMKAOCRGY FOEAKWCHEKYVPTYI DYMKLSYASLIDTFEE FERDLAPQGRSWCVKYAREEMIOMCRVYYQEAKWCHEKYSPTCD EYMKVSYASLIDTFEE FERDLAPQGRSWSVKYAREEMIOMCRVYYQEAKWCHEKYSPTCD DYMKVSYASLIDTFETFRRDLAPQGRSWSVKYAREEMIOMCRVYYQEAKWCHTKYSPTCD

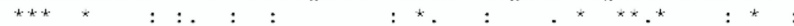
EY FONA-IKSSATTIMVVVSLLFNYDETDAKKT FESVSKNSKPQRATCIIGRFYDDLVEYMTNA-LVSSGYIMVTVIS-- FVGMGNVVTKET TOWASNNPRIVRASS I IARLNIDDIVS EYMSVA-LVTSGYTFITIIS--YLGMGE IASKEA FDWLFSHPPVIERSESVGRINIDDMRS EYMSNA-LVSSACSMI TMTS--FVGMGDIVTKEA FDWVISDPKMIRASNVICRIVDDIVS EYMSNA-LVSSACSML TRTS--EVGMGDIVTKEAFDWVISDPKMIRASNVICRIIDDIVS
EYMSVA-LLSSGYSLLATSS--FIGMGE IVSKEAFDWVISDPKI IRASTVIAR FIDDMTS EYMSVA-LLSSGYSLIATSS--FIGMGE IVSKEAFDWVI SDPKI IRASTVI AR FY IDDMTS EYMLVA-LVTSGSCI IATWS--FIGMGE IMT KEAFDWVI SDPKI ITASTVI FRI DDDIT EYMLVA-LVTSGSCILATWS--FIGMGE TMTKEAFDWVISDPKI ITASTVIFRIMIDDI T EYLNDAAITTAGYTI MSGTT--FLGMGEFATKAVFEWARETPKPTKABCI GR TOMAS EYLEKAS IVSFGYNLG'VVC--ELGMGDVATKEAFEWARGNPKVIRASCI TGRL GDIGS EYLEKA.SIVSFGYNIGTVVC--FLGMGDVATKFA EYLEKA.S IVSFGYNLGTVVC--FLGMGDVATKEAFEWARGNPKVVRAAGI IGRI DOIC

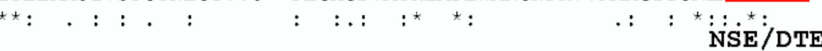

YEWDKHRDHVVGGVDCYIKOHSVSEEKAFEAINMVVENAWKE INEE I FESTMTIAKPLLP HK EQQRRHVASAI ECYMKQHGVSEEKACNE LNKQI ENAWKD INQE LVRPPAGVPMPVLT HK EQERGHVAS G I ECYMKQYGVTEEEAHDE FRKRLVKAWKDINEECLRP-YRVPKPLLT HE FEOKRGHVASAVECYMKOYGVSKEEAYDE FKKOVESAWKDNNEE FLQP-ZAVPVPLIT HK 'EQERCHVASGI ECYMKQCGVSEEQAYKE' HNQIVNAWLDINQECLKP-TAVPMPLLT HK FEOKRGHVASGIECYMKOYGVSEEOVYSE FHKOVENAWL GINOECLKP-TAVPMPLIT HK FOKRGHVASGTICVYKOYGVSEEOVYSTEHKOVENAWTDTNOECLKP-MAVPYPLT Y TEORDHVPSAVECYT-ZOHGVDEVTAOOELGKRVESG HH FEQRDHVPSAVECY IRQHGVDEVTAQRELGKRVESSWKD INEMMLKF-YMMPKPLL HIFEQGRDHVSAVECYIROHGVDEVTAORELGKRVESSWKDISEMMLKP-YMMPKPLLT

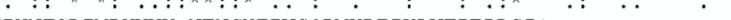
YIYNECRIMDYVYK-NENGYTIVSQRMKDT IKLVEIEPLSI * RILNLARVMDFLYK-EGDGYTHVGEAVKDGITSLMIDPIPIRILNLTRVIDVIYK-NFDGYTHVKKAMKDNTASLIIDPVIVRVLNESRMMDVLYK-DEDEYTLVGPLMKDLVAGMLIDPVPMRVT NTSRTMOVTVK-TGDGYTHVGKOMKDNTGSTLTDPTI--

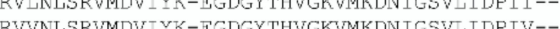
RTM RV RILNLSRVIEVFYRIGEDDYSIVSQNMQQKVELVIIHPVIVRILNECRTVDVIYK-GEDSYTESNHTMKNNISHILTDPIPIRILNECRIVDVIYK-GEDSYTFSNTTMKKNISHILTDPIPIRIPNECRIVDVIYK-GEDSYTESTTTMKKNISHILTDPIPI-

$:{ }^{*}::: *^{*}: \quad:{ }^{*}: \quad: \quad: \quad::{ }^{*}$

Figure 1. Comparison of the deduced amino acid sequence of PmSTPS1 and PmSTSP2, with other terpene synthase sequences of the highest sequence similarity. Polygonum minus sesquiterpene synthase 1 (MG921605); Polygonum minus sesquiterpene synthase 2 (MG921606); Persicaria hydropiper drimenol synthase (AHF22834.1); Persicaria minor putative sesquiterpene synthase (ALO69830.1); Theobroma cacao Delta-cadinene synthase isozyme A (XP_00702113.1); Beta vulgaris subs. vulgaris probable sesquiterpene synthase (XP_010694277.1); Santalum murrayanum probable sesquiterpene synthase (F6M8H1); Vitis vinifera (-)-Germacrene D synthase (XP_002282488.1); Vitis vinifera Valencene synthase (NP_001268028.1); and Vitis vinifera Germacrene A synthase (ADR61821.1). Amino acid residues conserved in all of the genes are marked with asterisk [*]. Amino acid residues conserved in four or five genes are indicated by double dots [:]. The universally conserved DDxxD, RxR motifs, and NSE/DTE are highlighted in boxes.

\subsection{Phylogenetic Analysis of P. minus Sesquiterpene Synthase (PmSTPS)}

The PmSTPS1 and PmSTPS2 amino acid sequences were aligned and compared with other flowering plant terpene synthase sequences, using Clustal Omega (Figure 2), and they showed a low sequence similarity (42.94\%). The phylogenetic analysis showed a particularly close relationship between the PmSTPS1 and PmSTPS2 amino acid sequences. The PmSTPS1 was clustered in the same clade with sesquiterpene synthase (PmSTS) from Persicaria minor and drimenol synthase from Persicaria hydropiper. The results showed that the 
PmSTPS1 from P. minus was grouped into a single clade with a $43.04 \%$ identity, which suggested a monophyletic origin of the gene. Additionally, PmSTPS2 was placed in the same clade with (+) delta-cadinene synthase from Ricinus communis. Moreover, PmSTPS1 and PmSTPS2 were grouped together with the terpene synthases from the Santalum and Vitis vinifera species. Multiple sequence alignments of PmSTPS1 and PmSTPS2 amino acid sequences, with sesquiterpenes from other plants species, showed a high sequence similarity (42-96\%).

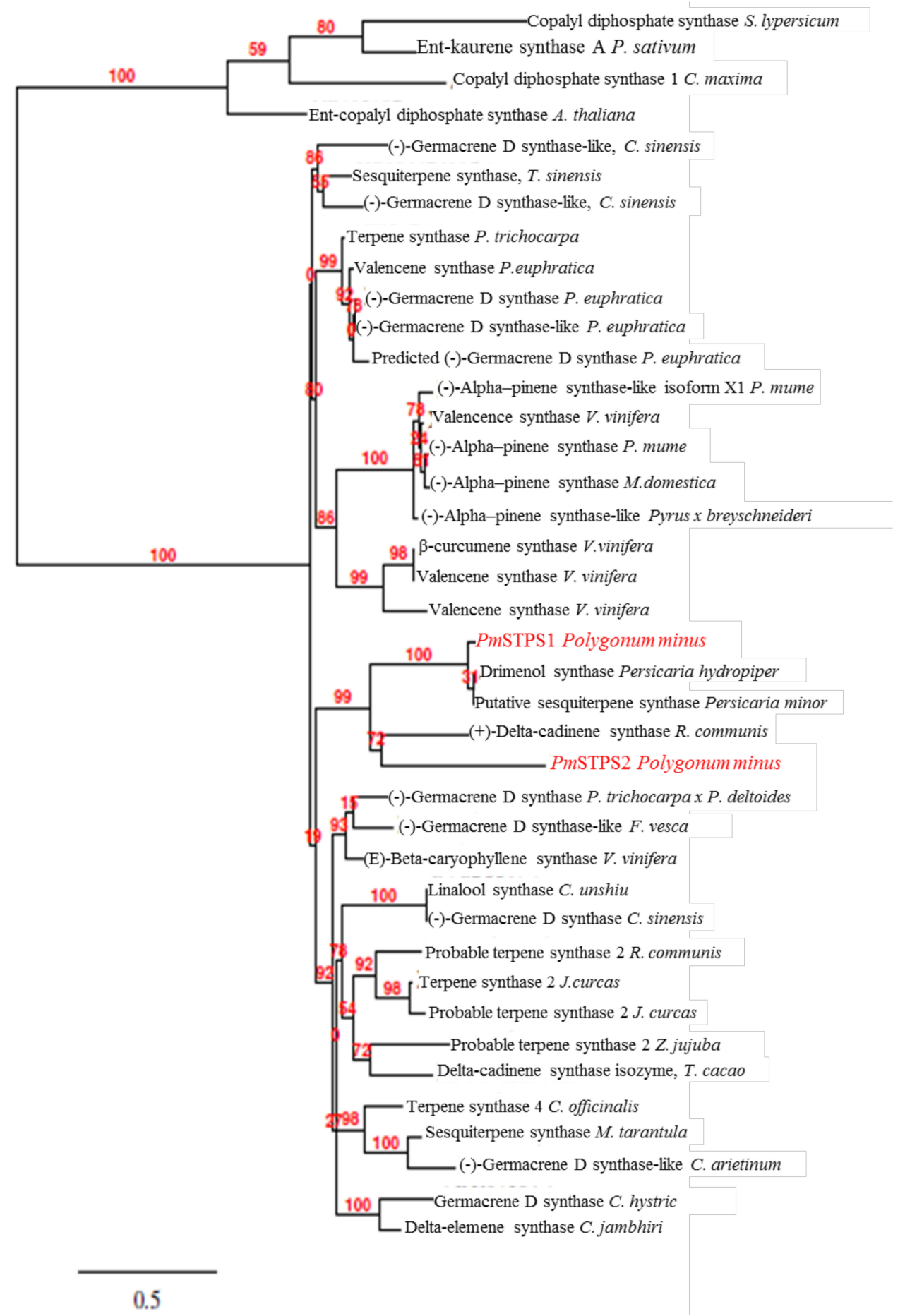

Figure 2. Phylogenetic tree of PmSTPS1 and PmSTPS2 protein sequences with amino acid sequences, with selected terpene synthases from other plants. The alignment was performed using the Clustal Omega algorithm. The tree was built using the neighbor-joining method and 1000 replicates for bootstrapping. The numbers indicated are the actual bootstrap values of the branches. 


\subsection{Expression of PmSTPS1 and PmSTPS2 in E. coli}

For the analysis of the protein expression, recombinant bacterial strains harbouring pQE2 in E. coli M15 with PmSTPS1 and PmSTPS2 were compared with those harbouring the control empty pQE2 vector. The cells were harvested at different times $(1,3$, and $5 \mathrm{~h}$ ) post-induction. After sonication and centrifugation of the bacteria, soluble and insoluble crude fractions were separated with 10\% SDS-PAGE. The SDS-PAGE analysis (Figure S3) showed unclear corresponding protein bands at the expected size at different post-induction times, as well as in the control sample. However, Western Blotting (Figure S4) confirmed the correct size of recombinant proteins. There was no band was observed in the control sample as expected. Correct protein sizes of 40.9 and 65.9 kDa were obtained for PmSTPS1 and PmSTPS2, respectively. From these findings, the recombinant PmSTPS1 and PmSTPS2 proteins from P. minus were successfully expressed in E. coli, and the activities of these enzymes were further investigated via enzymatic assays.

\subsection{Identification of PmSTPS1 and PmSTPS2 Assay Products}

A functional characterisation of the PmSTPS1 and PmSTPS2 genes was performed by an in vitro enzyme assay of the recombinant proteins. In this crude protein assay, the E. coli strain harbouring empty pQE-2 vector was used as the control strain. A GC-MS analysis showed that PmSTPS1 and PmSTPS2 produced $\beta$-farnesene, $\alpha$-farnesene, and farnesol as the final products. Additionally, PmSTPS2 also produced nerolidol. For PmSTPS1, the products formed were $\beta$-farnesene (14.49 min), $\alpha$-farnesene (15.79 $\mathrm{min})$, and farnesol (16.98 $\mathrm{min})$. Additionally, the principle products from PmSTPS2 enzyme were $\beta$-farnesene (14.49 min), $\alpha$-farnesene (15.83 min), farnesol (16.84 min), and nerolidol (17.25 min). Based on the GC-MS analysis, both extracts from PmSTPS1 and PmSTPS2 showed multiple peaks for corresponding sesquiterpene products, compared with no peaks observed in the control sample, which did not exhibit any major products, although exogenous substrates were added (Figure 3). These findings therefore demonstrated the successful production of sesquiterpenes in the recombinant $E$. coli strains overexpressing PmSPTS1 and PmSTPS2 enzymes, respectively.

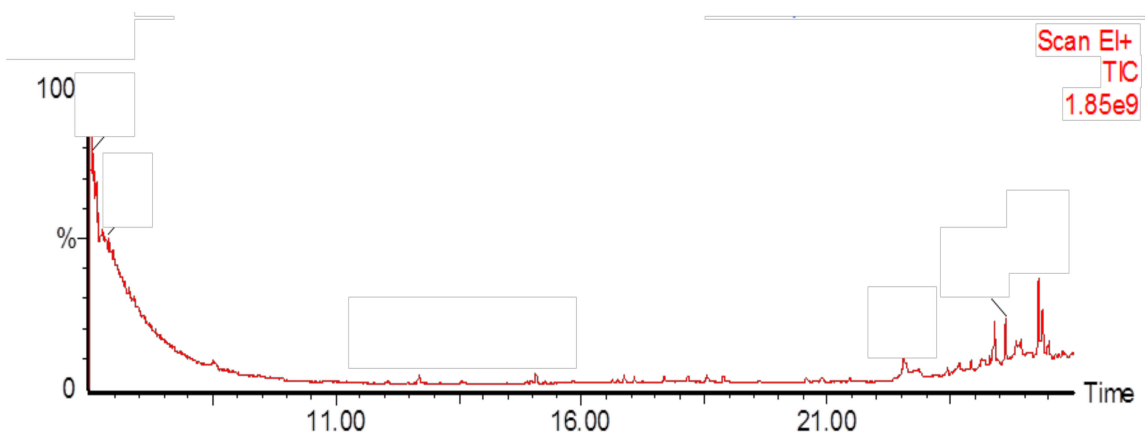

(a)

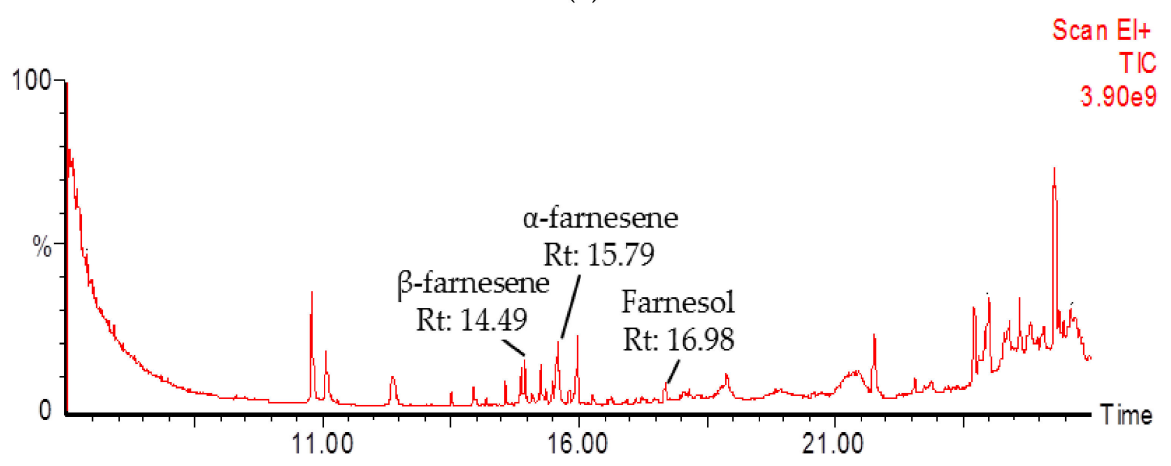

(b)

Figure 3. Cont. 


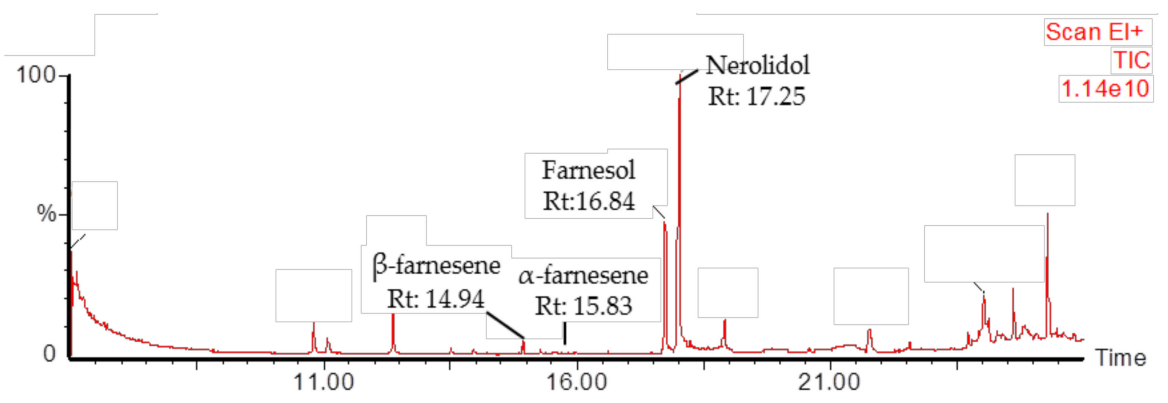

(c)

Figure 3. GC-MS chromatogram of products formed by crude PmSTPS1 and PmSTPS2 protein at different retention times (RT). (a) The chromatogram of control used consisted of M15 E. coli host harboring empty pQE-2 taqzyme plasmid; (b) PmSTPS1 (c); and PmSTPS2.

All of the peaks were further confirmed by comparison with NIST and Wiley libraries, mass spectra, authentic sesquiterpene standards, and control (Figure S5). Interestingly, although the sizes of PmSTPS1 and PmSTPS2 were different, the two enzymes were capable of producing similar sesquiterpene products, $\beta$-farnesene, $\alpha$-farnesene, and farnesol (Figure 3 ), but they did so at different levels. PmSTPS1 successfully converted the precursor FPP to produce $9.50 \% \beta$-farnesene as the main product, followed by $8.86 \% \alpha$-farnesene, and $5.08 \%$ farnesol. PmSTPS 2 showed synthesises nerolidol $(48.33 \%)$ as a major product, followed by farnesol $(15.30 \%), \beta$-farnesene $(5.07 \%)$, and $\alpha$-farnesene $(2.76 \%)$. Although the (E,E)-farnesyl pyrophosphate (FPP) substrate was added to the enzymatic assay, the control pQE-2 sample did not produce any significant products, indicating that endogenous metabolites did not affect the protein expression and analysis in this study.

\section{Discussion}

In this study, we provided the first cloning and functional characterisation of PmSTPS1 encoding a putative $\beta$-farnesene synthase, and PmSTPS2 encoding a putative nerolidol synthase in P. minus. A sequence comparison between the PmSTPS1 and PmSTPS2 indicated that the two enzymes had different protein and nucleotide sequences. However, both of the enzymes were structurally similar to other plant sesquiterpene synthases and contained all of the conserved motifs, including DDxxD, RXR, and NSE/EDTA, which were important for terpene synthase functionality $[5,45,46]$. Based on the phylogenetic analysis, PmSTPS1 and PmSTPS2 clustered on the same group with four distinct sesquiterpene synthases.

In addition, the unexpected band in the upper layer (Figure S4) might have been caused by protease aggregation, according [47]. As shown in several recent studies, the protein sizes of a few plants sesquiterpene synthases showed a nearly similar molecular weight, with PmSTPS2 within the range of $60-70 \mathrm{kDa}[24,48,49]$. In general, terpene synthase could be classified into monoterpene, sesquiterpene, and diterpene synthase, with 550-860 amino acids encoding a 50-100 kDa protein $[4,50]$. As a result of the absence of the signal peptide sequence with 50-70 amino acids, the size of sesquiterpene synthases were typically smaller than those of the monoterpenes and diterpenes [51]. Ee et al. [37] also reported that the protein size of the P. minus $\beta$-sesquiphelandrene synthase was $65.1 \mathrm{kDa}$. Additionally, studies on $\beta$-caryophyllene synthase, that were encoded by OkBCS (GenBank accession no. KP226502) from Ocimum kilimandscharicum Gürke, showed a molecular weight of $63.6 \mathrm{kDa}$ [24]. Until recently, no short sesquiterpene synthase sequence was characterised as a PmSTPS1. However, the short-chain length of this enzyme could be associated with several prenyltransferase (PT) enzymes. Based on previous findings, two prenyltranferases, Santalum farnesyl diphosphate synthase (SaFDS) and Hedychium farnesyl pyrophosphate synthase (HcFPPs), comprising 1029 and $1068 \mathrm{bp}$ nucleotide sequences and encoding polypeptides of 343 and 356 amino acids, respectively, were reported [3,52]. 
Many terpene synthases (TPSs) had the ability to synthesise one or multiple products from a single substrate, regardless of whether it was farnesyl pyrophosphate (FPP) or geranyl pyrophosphate (GPP) [53,54]. In addition, the sesquiterpene synthases from different plant species produced more than one product $[25,55,56]$. Interestingly, although the sizes of PmSTPS1 and PmSTPS2 were different, the two enzymes produced similar sesquiterpene products ( $\beta$-farnesene, $\alpha$-farnesene, and farnesol, Figure 3), albeit at different percentages. Both PmSTPS1 and PmSTSP2 could catalyse the formation of $\beta$-farnesene, $\alpha$-farnesene, nerolidol, and farnesol, whose functions were different from those of the previous STPS enzymes characterised in P. minus [36-39]. In addition, the enzymes demonstrated an inherent capacity for TPS enzymes to evolve different products and substrate specificities [57]. Moreover, the main factor of sesquiterpene diversity was the large number of different sesquiterpene synthases expressed in plants and the ability of some sesquiterpene synthases to form multiple products from a single FPP substrate [58].

Based on previous chemical profiling studies of $P$. minus essential oils from hydro-distillation extraction, low levels of nerolidol and farnesol were detected at $0.24 \%$ and $0.14 \%$, respectively [34]. A similar finding was reported, which indicaed that the percentage of $\beta$-farnesene and $\alpha$-farnesene compounds were also found at $0.92 \%$ and $0.82 \%$, respectively $[31,32,34]$. The percentage of terpenes that were obtained directly from the GC-MS analysis of $P$. minus leaf essential oil was lower compared with the products that were produced by the enzymatic assay of crude protein PmSTPS1 and PmSTPS2. The variation in composition could have been because of the variable amounts of sesquiterpenes that were produced in the plants, depending on environmental factors. Nevertheless, the sesquiterpenoids that were produced by in vitro assay potentially contributed to the plant fragrance, because most of the acyclic sesquiterpenes compounds, namely, farnesene, nerolidol, and farnesol, were previously reported in various plant essential oils $[21,59,60]$. These compounds could be potentially commercialised as fragrances, flavouring agents, or pharmaceutical products. In addition, farnesene is an important compound for diesel and jet fuels [61]. Understanding the physiological and ecological roles of plant volatile sesquiterpenes has been challenging. Several sesquiterpenes compounds might have acted as defense chemicals against biological stresses. For instance, E,E- $\alpha$-farnesene was reported to have potential for use as an alarm pheromone in the control of aphid pests [62]. Furthermore, the existence of farnesol in P. minus essential oil could have been related to the biosynthetic pathway of juvenile hormone (JH) III [63]. Nerolidol was not only used in cosmetics and non-cosmetic products [64], but was also proven to possess pharmacological and biological activities $[65,66]$. Therefore, the advantages of nerolidol have made it a promising drug candidate for industrial production $[67,68]$.

\section{Materials and Methods}

\subsection{Plant Material}

P. minus plants was grown in an experimental plot at Universiti Kebangsaan Malaysia (UKM) under natural light and environmental conditions. The samples were originally collected from Ulu Yam, Selangor, Malaysia (UY; $3^{\circ} 16^{\prime} 14.63^{\prime \prime} \mathrm{N}, 101^{\circ} 41^{\prime} 11.32^{\prime \prime} \mathrm{E}$ ), and were identified using ITS sequences [69]. The voucher specimens were deposited at the UKM herbarium. Leaf samples from P. minus plants were harvested in the morning, between 8 to $9 \mathrm{am}$, frozen in liquid nitrogen, and stored at $-80^{\circ} \mathrm{C}$ for RNA extraction.

\subsection{RNA Isolation and $c D N A$ Synthesis}

Total RNA was isolated and extracted as it was previously reported [70]. The quantity, purity, and integrity of the RNA were determined using standard methods. Three micrograms of RNA were reverse transcribed into cDNA using the Onetaq ${ }^{\circledR}$ One-step RT-PCR kit (New England Biolabs, Ipswich, MA, USA), according to manufacturer's instructions. 


\subsection{Candidate Gene Selection and Isolation of Full-Length PmSTPS1 and PmSTPS2}

The candidate gene selection was achieved by mining the P. minus transcriptome data [40] for transcripts that were related to the sesquiterpene biosynthetic pathway. The assembled transcripts were classified as sesquiterpene synthase, based on homology search, and the terpene synthases were selected and fully sequenced prior to further analysis. Two new P. minus sesquiterpene synthase (PmSTPS) candidate genes were identified. The predicted ORFs for PmSTPS1 (GenBank accession no: MG921605) and PmSTPS2 (GenBank accession no: MG921606) were amplified by PCR, using the Q5 High-Fidelity DNA Polymerase (NewEngland Biolabs, Ipswich, MA, USA). The cDNA-gene specific PCR primers were PmSTPS1_F (5'-AAAGGTACCATGCCAA GGCTCG-3') and PmSTPS1_R (5'-TTTGTCGACAATCGGAATGGGAT-3'); PmSTPS2_F (5'-AAAGGTACCATGTCAT

CCCAAA-3'), and PmSTPS2_R (5'-TTTAAGCTTAATGGAGAGAGGTT-3') were synthesized to amplify the $5^{\prime}$ end and $3^{\prime}$ end, respectively.

The PCR reaction mixture contained $1 \times$ reaction buffer, $2 \mathrm{mM} \mathrm{MgCl}, 0.2 \mathrm{mM}$ dNTPs, 5 units of Taq polymerase (Promega, Madison, WI, USA), $0.5 \mu \mathrm{M}$ of forward and reverse primers, and $20 \mathrm{ng}$ of template cDNA. The reaction was performed under the following conditions: pre-denaturation at $98^{\circ} \mathrm{C}$ for $30 \mathrm{~s}$, followed by 32 cycles of $98^{\circ} \mathrm{C}$ for $10 \mathrm{~s}, 60{ }^{\circ} \mathrm{C}$ for $10 \mathrm{~s}$, and $72{ }^{\circ} \mathrm{C}$ for $20 \mathrm{~s}$, with a final extension at $72{ }^{\circ} \mathrm{C}$ for $2 \mathrm{~min}$. The amplicons were digested with KpnI/SalI and KpnI/HindIII before being cloned into pUC19 and pUC57-Kan cloning vectors, respectively. The ligation mixtures were transformed into E. coli top 10 competent cells, before sub-cloning into the pQE-2 plasmid. The positive transformants were screened on LB agar that were supplemented with $100 \mu \mathrm{g} / \mathrm{mL}$ ampicillin, $20 \mu \mathrm{g} / \mathrm{mL}$ X-gal, and $0.1 \mathrm{mM}$ IPTG (ThermoFisher Scientific, Waltham, MA, USA). The recombinant plasmids pQE-2:PmSTPS1 and pQE-2:PmSTPS2 were then transformed into the E. coli M15 competent cells and the transformants were selected on LB agar that was supplemented with $50 \mu \mathrm{g} / \mathrm{mL}$ kanamycin. The positive transformants were confirmed by colony PCR, and the gene sequences were verified via DNA sequencing (First BASE Laboratories, Seri Kembangan, Selangor, Malaysia).

\subsection{Full-Length cDNA Sequence Analysis and Phylogenetic Tree Construction}

The ORF for PmSTPS1 and PmSTPS2 were predicted using the ORF finder program (http:/ / www.ncbi.nlm.nih.gov) and were subjected to BLASTX and BLASTP analyses. Multiple sequence alignment was achieved using the Clustal Omega pairwise alignment algorithm. Verification of the cDNA sequence, including the amino acid sequence, theoretical isoelectric point (pI), and predicted molecular weight (MW) of the analyses, was performed using ExPASy Proteomic tools (http://www.cn.expasy.org/tools/protscale.html). The physical and chemical characteristics of all of the deduced amino acid sequences were analysed by the ProtParam tool (http:/ / web.expasy.org/program/). The signal peptide targeting location of the deduced proteins was predicted using the SignalP method (http:/ / www.cbs.dtu.dk/services/SignalP) and ChloroP program (http:/ / www.cbs.dtu.dk/services/ChloroP/). A protein domain analysis was performed using the SMART (Simple Modular Architectural Research Tool) database (http:/ / smart.embl-heidelberg.de/).

\subsection{Phylogenetic Analysis}

Phylogenetic and molecular evolutionary analyses of the amino acid sequences of the PmSTPS1 and PmSTPS2 from different plant species were constructed using the default parameters of PhyML software, which were available at Phylogeny.fr web services (www.phylogeny.fr/version2_cgi/ simplephylogeny.cgi) [71]. PhyML was employed to construct a phylogenetic tree, by generating multiple alignments through the neighbour-joining computational method.

\subsection{Expression of PmSTPS1 and PmSTPS2 in E. coli}

A single colony of recombinant E. coli M15 cells harbouring pQE-2:PmSTPS1, pQE2:PmSTPS2, and empty pQE-2 (as a negative control) were inoculated into $10 \mathrm{~mL}$ of an LB medium containing 
kanamycin $(50 \mu \mathrm{g} / \mathrm{mL})$, and were grown overnight at $37^{\circ} \mathrm{C}$. Approximately $2 \mathrm{~mL}$ of the cultures were added to $200 \mathrm{~mL}$ of fresh $\mathrm{LB}$, which contained $50 \mu \mathrm{g} / \mathrm{mL}$ kanamycin. The cultures were induced with $0.5 \mathrm{mM}$ IPTG at OD600 0.5. The cultures were incubated for 1,3 , and $5 \mathrm{~h}$ at $37^{\circ} \mathrm{C}$, and were then harvested by centrifugation at $4000 \times g$ for $30 \mathrm{~min}$ at $4{ }^{\circ} \mathrm{C}$. Subsequently, the bacteria were resuspended in $100 \mathrm{~mL}$ of $25 \mathrm{mM}$ sodium phosphate buffer, $\mathrm{pH} 7.5$, containing $0.5 \mathrm{M}$ Tris- $\mathrm{HCl}, 5 \%$ glycerol, $1 \mathrm{mM}$ dithiothreitol (DTT), $10 \mathrm{mM} \mathrm{MgCl}, 1 \mathrm{mM} \mathrm{MnCl}_{2}, \mathrm{pH} 7.5$, and $1 \mathrm{mM}$ lysozyme (Sigma-Aldrich, St. Louis, MI, USA) [20]). The cells were sonicated for $2 \mathrm{~min}$ at $5 \mathrm{~s}$ pulses, with $5 \mathrm{~s}$ between the pulses on ice, using the Sonic Dismembrator Model 100 (Fisher Scientific, Hampton, NH, USA). The cell lysate was then centrifuged at $10,000 \times g$ for $30 \mathrm{~min}$ at $4{ }^{\circ} \mathrm{C}$.

\subsection{Enzyme Assay}

A standard assay was done according to a previous method, with slight modifications. Standard assays were performed in $2.5 \mathrm{~mL}$ glass GC vials containing $200 \mu \mathrm{g}$ of crude protein mixed with $50 \mathrm{mM}$ Tris (pH 7.5), $10 \mathrm{mM} \mathrm{MgCl}$, and $100 \mu \mathrm{M}$ of (E,E)-farnesyl pyrophosphate (FPP) (Sigma-Aldrich, St. Louis, MI, USA). The reaction mixture with a total volume of $200 \mu \mathrm{L}$ was vortexed, overlaid with $500 \mathrm{~mL}$ hexane, and incubated at $30^{\circ} \mathrm{C}$ for $2 \mathrm{~h}$. The hexane phase was concentrated to $200 \mathrm{~mL}$ by passing $\mathrm{N}_{2}$ at the opening of the tube and was then further used for the GC-MS analysis.

\subsection{Detection of Sesquiterpenes Using GC-MS}

The samples were analysed using a Clarus 600 GC-MS (PerkinElmer Inc., Waltham, MA, USA) that was equipped with a capillary column (Elite- $530 \mathrm{~m} \times 0.25 \mathrm{~mm}$, film thickness $0.25 \mu \mathrm{m}$ ). The GC was operated at a flow rate of $2 \mathrm{~mL} / \mathrm{min}$, and the mass selector detector (MSD) was operated at $70 \mathrm{eV}$. Splitless injections $(1.5 \mu \mathrm{L})$ were performed with an injector temperature of $250{ }^{\circ} \mathrm{C}$. The GC system was programmed with an initial oven temperature of $50^{\circ} \mathrm{C}$ ( $5 \mathrm{~min}$ hold), which was then increased to $180^{\circ} \mathrm{C}$ at $10^{\circ} \mathrm{C} / \mathrm{min}\left(4 \mathrm{~min}\right.$ hold), followed by a $100{ }^{\circ} \mathrm{C} / \mathrm{min}$ ramp at $240{ }^{\circ} \mathrm{C}(1 \mathrm{~min}$ hold $)$. A solvent delay of $8.5 \mathrm{~min}$ was allowed before the acquisition of the MS data. The MS system was operated in selected ion monitoring (SIM) mode to scan for the molecular ions at product peaks, which were quantified by the integration of peak areas with library search, using the NIST library [72].

\section{Conclusions}

In summary, two new sesquiterpene synthases, PmSTPS1 and PmSTPS2, which were identified from P. minus leaf transcriptomics analysis, were cloned and characterised. Both of the enzymes produced industrially important acyclic sesquiterpenes, $\beta$-farnesene, $\alpha$-farnesene, and farnesol. PmSTPS2 also produced nerolidol as the major product from FPP conversion. This study demonstrated the production of P. minus characteristic fragrance-related sesquiterpenes, by both PmSTPS1 and PmSTP, as well as the potential of further metabolic engineering in E. coli, using PmSTPS2 for the microbial production of nerolidol.

Supplementary Materials: The following are available online, Figure S1: Nucleotide and predicted amino acid sequence of PmSPTS1 and from P. minus; Figure S2: Nucleotide and predicted amino acid sequence of PmSTPS2 from P. minus.; Figure S3: SDS-PAGE analysis of recombinant pQE2_PmSTPS1 and pQE2-PmSTPS2 proteins is marked with red box and molecular mass markers are indicated; Figure S4: The expression analysis of PmSTPS1and PmSTPS2 in E. coli M15 after 0.5 mM IPTG induction at 1, 3, and 5 h; and Figure S5: Mass spectra of major three sesquiterpenes produced by recombinant PmSTPS1 and PmSTPS2 in comparison with the mass spectra from authentic standards.

Author Contributions: N.A.R. and S.N.B. conceived and designed all of the experiments; N.A.R. performed the experiments and analysed the data; S.N.B. and H-H.G. contributed reagents/materials/analysis tools; N.A.R., S.N.B., H-H.G., S.S., A.B.R., and N.M.N. wrote and edited the paper. All of the authors reviewed the manuscript.

Funding: This research was funded by Research University Grants from Universiti Kebangsaan Malaysia [UKM-GUP-2013-028 and DLP 2013-024] awarded to Syarul Nataqain Baharum. We also acknowledge the Centre for Research and Instrumentation Management (CRIM), UKM for a Research Instrumentation Development Grant 2010 (PIP-CRIM). The publication fee was supported by DPP-2018-010 awarded to INBIOSIS, UKM. 
Acknowledgments: The authors thank Kamarul Azlan Azizan and Syahmi Afiq Mustaza for their technical assistance and the reviewers for constructive comments.

Conflicts of Interest: The authors declare no conflict of interest.

\section{References}

1. McCaskill, D.R.C. Prospects for the Bioengineering of Isoprenpid Biosynthesis. In Biotechnology of Aroma Compounds. Advances in Biochemical Engineering/Biotechnology; Springer: Berlin/Heidelberg, Germany, 1997; pp. 107-146.

2. Lange, B.M.; Ahkami, A. Metabolic Engineering of Plant Monoterpenes, Sesquiterpenes and Diterpenes-Current Status and Future Opportunities. Plant Biotechnol. J. 2013, 11, 169-196. [CrossRef] [PubMed]

3. Lan, J.B.; Yu, R.C.; Yu, Y.Y.; Fan, Y.P. Molecular Cloning and Expression of Hedychium coronarium Farnesyl Pyrophosphate Synthase Gene and Its Possible Involvement in the Biosynthesis of Floral and Wounding/herbivory Induced Leaf Volatile Sesquiterpenoids. Gene 2013, 518, 360-367. [CrossRef] [PubMed]

4. Bohlmann, J.; Meyer-Gauen, G.; Croteau, R. Plant Terpenoid Synthases: Molecular Biology and Phylogenetic Analysis. Proc. Natl. Acad. Sci. USA 1998, 95, 4126-4133. [CrossRef] [PubMed]

5. Degenhardt, J.; Köllner, T.G.; Gershenzon, J. Monoterpene and Sesquiterpene Synthases and the Origin of Terpene Skeletal Diversity in Plants. Phytochemistry 2009, 70, 1621-1637. [CrossRef] [PubMed]

6. Tholl, D.; Lee, S. Terpene Specialized Metabolism in Arabidopsis thaliana. Arabidopsis Book 2011, 9, e0143. [CrossRef] [PubMed]

7. Christianson, D.W. Structural and Chemical Biology of Terpenoid Cyclases. Chem. Rev. 2017, 117, 11570-11648. [CrossRef] [PubMed]

8. Kuzuyama, T. Mevalonate and Nonmevalonate Pathways for the Biosynthesis of Isoprene Units. Biosci. Biotechnol. Biochem. 2002, 66, 1619-1627. [CrossRef] [PubMed]

9. Eisenreich, W.; Bacher, A.; Arigoni, D.; Rohdich, F. Biosynthesis of Isoprenoids via the Non-Mevalonate Pathway. Cell. Mol. Life Sci. 2004, 61, 1401-1426. [CrossRef] [PubMed]

10. Goldstein, J.L.; Brown, M.S. Regulation of the Mevalonate Pathway. Nature 1993, 295, 517-524. [CrossRef] [PubMed]

11. Rohmer, M. The Mevalonate-Independent Methylerythritol 4-Phosphate (MEP) Pathway for Isoprenoid Biosynthesis, Including Carotenoids. Pure Appl. Chem. 1999, 71, 2279-2284. [CrossRef]

12. Chandran, S.S.; Kealey, J.T.; Reeves, C.D. Microbial Production of Isoprenoids. Process Biochem. 2011, 46, 1703-1710. [CrossRef]

13. Keasling, J.D. Synthetic Biology and the Development of Tools for Metabolic Engineering. Metab. Eng. 2012, 14, 189-195. [CrossRef] [PubMed]

14. Peralta-Yahya, P.P.; Ouellet, M.; Chan, R.; Mukhopadhyay, A.; Keasling, J.D.; Lee, T.S. Identification and Microbial Production of a Terpene-Based Advanced Biofuel. Nat. Commun. 2011, 2, 483. [CrossRef] [PubMed]

15. Schwab, W.; Davidovich-Rikanati, R.; Lewinsohn, E. Biosynthesis of Plant-Derived Flavor Compounds. Plant J. 2008, 54, 712-732. [CrossRef] [PubMed]

16. Srivastava, P.L.; Daramwar, P.P.; Krithika, R.; Pandreka, A.; Shankar, S.S.; Thulasiram, H.V. Functional Characterization of Novel Sesquiterpene Synthases from Indian Sandalwood, Santalum album. Sci. Rep. 2015, 5, 10095. [CrossRef] [PubMed]

17. Paddon, C.J.; Keasling, J.D. Semi-Synthetic Artemisinin: A Model for the use of Synthetic Biology in Pharmaceutical Development. Nat. Rev. Microbiol. 2014, 12, 355. [CrossRef] [PubMed]

18. Aschenbrenner, A.-K.; Kwon, M.; Conrad, J.; Ro, D.-K.; Spring, O. Identification and Characterization of Two Bisabolene Synthases from Linear Glandular Trichomes of Sunflower (Helianthus annuus L., Asteraceae). Phytochemistry 2016, 124, 29-37. [CrossRef] [PubMed]

19. Pazouki, L.; Memari, H.R.; Kännaste, A.; Bichele, R.; Niinemets, Ü. Germacrene A Synthase in Yarrow (Achillea millefolium) is an Enzyme with Mixed Substrate Specificity: Gene Cloning, Functional Characterization and Expression Analysis. Front. Plant Sci. 2015, 6, 111. [CrossRef] [PubMed]

20. Kwon, M.; Cochrane, S.A.; Vederas, J.C.; Ro, D.K. Molecular Cloning and Characterization of Drimenol Synthase from Valerian Plant (Valeriana Officinalis). FEBS Lett. 2014, 588, 4597-4603. [CrossRef] [PubMed] 
21. Parveen, I.; Wang, M.; Zhao, J.; Chittiboyina, A.G.; Tabanca, N.; Ali, A.; Baerson, S.R.; Techen, N.; Chappell, J.; Khan, I.A.; et al. Investigating Sesquiterpene Biosynthesis in Ginkgo biloba: Molecular Cloning and Functional Characterization of (E,E)-Farnesol and $\alpha$-Bisabolene Synthases. Plant Mol. Biol. 2015, 89, 451-462. [CrossRef] [PubMed]

22. Yu, F.; Okamto, S.; Nakasone, K.; Adachi, K.; Matsuda, S.; Harada, H.; Misawa, N.; Utsumi, R. Molecular Cloning and Functional Characterization of $\alpha$-Humulene Synthase, a Possible Key Enzyme of Zerumbone Biosynthesis in Shampoo Ginger (Zingiber zerumbet Smith). Planta 2008, 227, 1291-1299. [CrossRef] [PubMed]

23. Attia, M.; Kim, S.; Ro, D. Catalyzing the First Step in the Biosynthesis of the Natural Sweetener, Hernandulcin, in Lippia dulcis. Arch. Biochem. Biophys. 2012, 527, 37-41. [CrossRef] [PubMed]

24. Jayaramaiah, R.H.; Anand, A.; Beedkar, S.D.; Dholakia, B.B.; Punekar, S.A.; Kalunke, R.M.; Gade, W.N.; Thulasiram, H.V.; Giri, A.P. Functional Characterization and Transient Expression Manipulation of a New Sesquiterpene Synthase Involved in $\beta$-Caryophyllene Accumulation in Ocimum. Biochem. Biophys. Res. Commun. 2016, 473, 265-271. [CrossRef] [PubMed]

25. König, J.C.; Scheper, T.; Beutel, S. Heterologous Expression, Purification, and Biochemical Characterization of $\alpha$-Humulene Synthase from Zingiber zerumbet Smith. Appl. Biochem. Biotechnol. 2016, 178, 474-489.

26. Picaud, S.; Olsson, M.E.; Brodelius, M.; Brodelius, P.E. Cloning, Expression, Puri W Cation and Characterization of Recombinant (+)-Germacrene D Synthase from Zingiber officinale. Arch. Biochem. Biophys. 2006, 452, 17-28. [CrossRef] [PubMed]

27. Abubakar, M.A.; Zulkifli, R.M.; Nur, W.; Wan, A.; Husni, A.; Shariff, M.; Ahmad, N.; Nik, N.; Zakaria, Z.; Ahmad, F. Antibacterial Properties of Persicaria minor (Huds.) Ethanolic and Aqueous-Ethanolic Leaf Extracts. J. Appl. Pharm. Sci. 2015, 5 (Suppl. 2), 50-56.

28. Christapher, P.V.; Parasuraman, S.; Christina, J.M.A.; Asmawi, M.Z.; Vikneswaran, M. Review on Polygonum minus. Huds, a Commonly Used Food Additive in Southeast Asia. Pharmacogn. Res. 2014, 7, 1. [CrossRef] [PubMed]

29. George, A.; Chinnappan, S.; Choudhary, Y.; Bommu, P.; Sridhar, M. Immunomodulatory Activity of an Aqueous Extract of Polygonum minus Huds on Swiss Albino Mice Using Carbon Clearance Assay. Asian Pac. J. Trop. Dis. 2014, 4, 398-400. [CrossRef]

30. Qader, S.W.; Abdulla, M.A.; Chua, L.S. Potential Bioactive Property of Polygonum minus Huds (Kesum) Review. Sci. Res. Essays 2012, 7, 90-93.

31. Ahmad, R.; Baharum, S.N.; Bunawan, H.; Lee, M.; Noor, N.M.; Rohani, E.R.; Ilias, N.; Zin, N.M. Volatile Profiling of Aromatic Traditional Medicinal Plant, Polygonum minus in Different Tissues and Its Biological Activities. Molecules 2014, 19, 19220-19242. [CrossRef] [PubMed]

32. Baharum, S.N.; Bunawan, H.; Ghani, A.; Aida, W.; Mustapha, W.; Noor, N.M. Analysis of the Chemical Composition of the Essential Oil of Polygonum minus Huds. Using Two-Dimensional Gas Chromatography-Time-of-Flight Mass Spectrometry (GC-TOF MS). Molecules. [CrossRef] [PubMed]

33. Yaacob, K.B.; Noor Salleh, A.; Joulain, D. Studies on Polygonum Spp. In Proceedings of the 12th International Congress of Flavours Fragrances and Essential Oils, Vienna, Austria, 4-8 October 1992; pp. 491-498.

34. Rusdi, N.A.; Goh, H.H.; Baharum, S.N. GC-MS/Olfactometric Characterisation and Aroma Extraction Dilution Analysis of Aroma Active Compounds in Polygonum minus Essential Oil. Plant Omics 2016, 9, 289-294. [CrossRef]

35. Tan, E.; Othman, R. Characterization of $\alpha$-Farnesene Synthase Gene from Polygonum minus. Trans. Malaysian Soc. Plant Physiol. 2012, 20, 155-157.

36. Song, A.A.-L.; Abdullah, J.O.; Abdullah, M.P.; Shafee, N.; Othman, R.; Tan, E.-F.; Noor, N.M.; Raha, A.R. Overexpressing 3-Hydroxy-3-Methylglutaryl Coenzyme A Reductase (HMGR) in the Lactococcal Mevalonate Pathway for Heterologous Plant Sesquiterpene Production. PLoS ONE 2012, 7, e52444. [CrossRef] [PubMed]

37. Ee, S.; Othman, R.; Shaharuddin, N.A.; Ismail, I.; Zainal, Z. Functional Characterization of Sesquiterpene Synthase from Polygonum minus. Sci. World J. 2014, 2014. [CrossRef] [PubMed]

38. Kiat, C.J.; Ashraf, M.F.; Naeem-Ul-Hassan, M.; Che Mohd Zain, C.R.; Zainal, Z.; Ismail, I. Molecular Cloning, Characterization and Expression Pattern Analysis of a Jasmonic Acid Responsive Sesquiterpene Synthase Gene from Persicaria minor. Plant Omics 2016, 9, 360-368. [CrossRef]

39. Ker, D.-S.; Pang, S.L.; Othman, N.F.; Kumaran, S.; Tan, E.F.; Krishnan, T.; Chan, K.G.; Othman, R.; Hassan, M.; Ng, C.L. Purification and Biochemical Characterization of Recombinant Persicaria Minor $\beta$ -Sesquiphellandrene Synthase. PeerJ 2017, 5, e2961. [CrossRef] [PubMed] 
40. Loke, K.; Rahnamaie-tajadod, R.; Yeoh, C.; Goh, H.; Mohamed-Hussein, Z.; Mohd, N.; Zainal, Z.; Ismail, I. Genomics Data RNA-Seq Analysis for Secondary Metabolite Pathway Gene Discovery in Polygonum minus. GDATA 2016, 7, 12-13.

41. Chen, X.; Wang, Y.; Sun, J.; Wang, J.; Xun, H.; Tang, F. Cloning, Expression and Functional Characterization of Two Sesquiterpene Synthase Genes from Moso Bamboo (Phyllostachys edulis). Protein Expr. Purif. 2016, 120, 1-6. [CrossRef] [PubMed]

42. Hsieh, H.L.; Ma, L.T.; Wang, S.Y.; Chu, F.H. Cloning and Expression of a Sesquiterpene Synthase Gene from Taiwania cryptomerioides. Holzforschung 2015, 69, 1041-1048. [CrossRef]

43. Nagegowda, D.A.; Gutensohn, M.; Wilkerson, C.G.; Dudareva, N. Two Nearly Identical Terpene Synthases Catalyze the Formation of Nerolidol and Linalool in Snapdragon Flowers. Plant J. 2008, 55, 224-239. [CrossRef] [PubMed]

44. Zhang, Y.; Li, Z.; Yu, X.; Fan, J.; Pickett, J.A.; Jones, H.D.; Zhou, J.; Michael, A.; Caulfield, J.; Napier, J.A.; et al. Molecular Characterization of Two Isoforms of a Farnesyl Pyrophosphate Synthase Gene in Wheat and Their Roles in Sesquiterpene Synthesis and Inducible Defence against Aphid Infestation. New Phytol. 2015, 206, 1101-1115. [CrossRef] [PubMed]

45. Yahyaa, M.; Matsuba, Y.; Brandt, W.; Doron-Faigenboim, A.; Bar, E.; McClain, A.; Davidovich-Rikanati, R.; Lewinsohn, E.; Pichersky, E.; Ibdah, M. Identification, Functional Characterization, and Evolution of Terpene Synthases from a Basal Dicot. Plant Physiol. 2015, 169, 1683-1697. [CrossRef] [PubMed]

46. Alquézar, B.; Rodríguez, A.; de la Peña, M.; Peña, L. Genomic Analysis of Terpene Synthase Family and Functional Characterization of Seven Sesquiterpene Synthases from Citrus sinensis. Front. Plant Sci. 2017, 8. [CrossRef] [PubMed]

47. Mahmood, T.; Yang, P.C. Western Blot: Technique, Theory, and Trouble Shooting. N. Am. J. Med. Sci. 2012, 4.

48. Jin, J.; Kim, M.J.M.J.; Dhandapani, S.; Tjhang, J.G.; Yin, J.-L.J.-L.; Wong, L.; Sarojam, R.; Chua, N.-H.N.-H.; Jang, I.-C. The Floral Transcriptome of Ylang Ylang (Cananga odorata Var. Fruticosa) Uncovers Biosynthetic Pathways for Volatile Organic Compounds and a Multifunctional and Novel Sesquiterpene Synthase. J. Exp. Bot. 2015, 66, 3959-3975. [CrossRef] [PubMed]

49. Su, P.; Hu, T.; Liu, Y.; Tong, Y.; Guan, H.; Zhang, Y.; Zhou, J.; Huang, L.; Gao, W. Functional Characterization of NES and GES Responsible for the Biosynthesis of (E)-Nerolidol and (E,E)-Geranyllinalool in Tripterygium wilfordii. Sci. Rep. 2017, 7, 40851. [CrossRef] [PubMed]

50. Keeling, C.I.; Bohlmann, J. Genes, Enzymes and Chemicals of Terpenoid Diversity in the Constitutive and Induced Defence of Conifers against Insects and Pathogens. New Phytol. 2006, 170, 657-675. [CrossRef] [PubMed]

51. Trapp, S.C.; Croteau, R. Genomic Organization of Plant Terpene Synthases and Molecular Evolutionary Implications. Genetics 2001, 158, 811-832. [PubMed]

52. Mercke, P.; Crock, J.; Croteau, R.; Brodelius, P.E. Cloning, Expression, and Characterization of Epi-Cedrol Synthase, a Sesquiterpene Cyclase from Artemisia annua L. Arch. Biochem. Biophys. 1999, 369, $213-222$. [CrossRef] [PubMed]

53. Irmisch, S.; Krause, S.T.; Kunert, G.; Gershenzon, J.; Degenhardt, J.; Köllner, T.G. The Organ-Specific Expression of Terpene Synthase Genes Contributes to the Terpene Hydrocarbon Composition of Chamomile Essential Oils. BMC Plant Biol. 2012, 12, 84. [CrossRef] [PubMed]

54. Hsu, L.J.; Chu, F.H. Plasticity Residues Involved in Secondary Cyclization of Terpene Synthesis in Taiwania cryptomerioides. Tree Genet. Genomes 2015, 11, 796. [CrossRef]

55. Picaud, S.; Brodelius, M.; Brodelius, P.E. Expression, Purification and Characterization of Recombinant (E)- $\beta$-Farnesene Synthase from Artemisia annua. Phytochemistry 2005, 66, 961-967. [CrossRef] [PubMed]

56. Xie, X.; Kirby, J.; Keasling, J.D. Functional Characterization of Four Sesquiterpene Synthases from Ricinus communis (Castor Bean). Phytochemistry 2012, 78, 20-28. [CrossRef] [PubMed]

57. Green, S.A.; Chen, X.; Nieuwenhuizen, N.J.; Matich, A.J.; Wang, M.Y.; Bunn, B.J.; Yauk, Y.K.; Atkinson, R.G. Identification, Functional Characterization, and Regulation of the Enzyme Responsible for Floral (E)-Nerolidol Biosynthesis in Kiwifruit (Actinidia chinensis). J. Exp. Bot. 2012, 63, 1951-1967. [CrossRef] [PubMed]

58. Rosano, G.L.; Ceccarelli, E.A. Recombinant Protein Expression in Escherichia Coli: Advances and Challenges. Front. Microbiol. 2014, 5, 172. [CrossRef] [PubMed] 
59. Albertsen, L.; Chen, Y.; Bach, L.S.; Rattleff, S.; Maury, J.; Brix, S.; Nielsen, J.; Mortensen, U.H. Diversion of Flux toward Sesquiterpene Production in Saccharomyces cerevisiae by Fusion of Host and Heterologous Enzymes. Appl. Environ. Microbiol. 2011, 77, 1033-1040. [CrossRef] [PubMed]

60. Kitaoka, N.; Lu, X.; Yang, B.; Peters, R.J. The Application of Synthetic Biology to Elucidation of Plant Mono-, Sesqui-, and Diterpenoid Metabolism. Mol. Plant 2015, 8, 6-16. [CrossRef] [PubMed]

61. Tippmann, S.; Scalcinati, G.; Siewers, V.; Nielsen, J. Production of Farnesene and Santalene by Saccharomyces cerevisiae Using Fed-Batch Cultivations with R-Controlled Feed. Biotechnol. Bioeng. 2016, 113, 72-81. [CrossRef] [PubMed]

62. Šobotník, J.; Hanus, R.; Kalinová, B.; Piskorski, R.; Cvačka, J.; Bourguignon, T.; Roisin, Y. (E,E)- $\alpha$-Farnesene, an Alarm Pheromone of the Termite Prorhinotermes canalifrons. J. Chem. Ecol. 2008, 34, 478-486. [CrossRef] [PubMed]

63. Ahmad-Sohdi, N.A.S.; Seman-Kamarulzaman, A.F.; Mohamed-Hussein, Z.A.; Hassan, M. Purification and Characterization of a Novel NAD $(\mathrm{P})^{+}$-Farnesol Dehydrogenase from Polygonum minus Leaves. PLoS ONE 2015, 10, e0143310. [CrossRef] [PubMed]

64. Lapczynski, A.; Letizia, C.S.; Api, A.M. Fragrance Material Review on Cis-Nerolidol. Food Chem. Toxicol. 2008, 46, 245-246. [CrossRef] [PubMed]

65. Vinholes, J.; Gonçalves, P.; Martel, F.; Coimbra, M.A.; Rocha, S.M. Assessment of the Antioxidant and Antiproliferative Effects of Sesquiterpenic Compounds in in Vitro Caco-2 Cell Models. Food Chem. 2014, 156, 204-211. [CrossRef] [PubMed]

66. AbouLaila, M.; Sivakumar, T.; Yokoyama, N.; Igarashi, I. Inhibitory Effect of Terpene Nerolidol on the Growth of Babesia Parasites. Parasitol. Int. 2010, 59, 278-282. [CrossRef] [PubMed]

67. Chan, W.K.; Tan, L.T.H.; Chan, K.G.; Lee, L.H.; Goh, B.H. Nerolidol: A Sesquiterpene Alcohol with Multi-Faceted Pharmacological and Biological Activities. Molecules 2016, 529. [CrossRef] [PubMed]

68. Silva, M.P.N.; Oliveira, G.L.S.; De Carvalho, R.B.F.; De Sousa, D.P.; Freitas, R.M.; Pinto, P.L.S.; De Moraes, J. Antischistosomal Activity of the Terpene Nerolidol. Molecules 2014, 19, 3793-3803. [CrossRef] [PubMed]

69. Bunawan, H.; Choong, C.Y.; Md-Zain, B.M.; Baharum, S.N.; Noor, N.M. Molecular Systematics of Polygonum minus Huds. Based on ITS Sequences. Int. J. Mol. Sci. 2011, 12, 7626-7634. [CrossRef] [PubMed]

70. Abdul-Rahman, A.; Suleman, N.I.; Zakaria, W.A.; Goh, H.H.; Noor, N.M.; Aizat, W.M. RNA Extractions of Mangosteen (Garcinia mangostana L.) Pericarps for Sequencing. Sains Malaysiana 2017, 46, 1231-1240. [CrossRef]

71. Kong, S.L.; Abdullah, S.N.A.; Ho, C.L.; Amiruddin, M.D. Molecular Cloning, Gene Expression Profiling and in Silico Sequence Analysis of Vitamin E Biosynthetic Genes from the Oil Palm. Plant Gene 2016, 5, 100-108. [CrossRef]

72. Maille, P.E.O.; Chappell, J.; Noel, J.P. A Single-Vial Analytical and Quantitative Gas Chromatography-Mass Spectrometry Assay for Terpene Synthases. Anal. Biochem. 2004, 335, 210-217.

Sample Availability: Samples of the compounds $\beta$-farnesene and nerolidol are not available from the authors.

(C) 2018 by the authors. Licensee MDPI, Basel, Switzerland. This article is an open access article distributed under the terms and conditions of the Creative Commons Attribution (CC BY) license (http://creativecommons.org/licenses/by/4.0/). 